\title{
Strategi Pengembangan Usaha Kecil Dan Mikro Serta Dampak Kesejahteraan Masyarakat Desa Kweden Kecamatan Tarik Kabupaten Sidoarjo (Menurut Pandangan Maqashid Syariah)
}

\author{
Fai'zah Laila Maulidah" ${ }^{1)}$, Renny Oktafia ${ }^{2)}$ \\ ${ }^{1,2}$ Fakultas Agama Islam, Universitas Muhammadiyah Sidoarjo (Fai'zah Laila Maulidah) \\ *Email korespondensi: Faizahlaila29@gmail.com
}

\begin{abstract}
The development of the times, many small and medium enterprises have sprung up, because by establishing these small and medium enterprises will increse income and help the surrounding community. So that this bussiness will have an impact on the welfare of the community. The purpose of this research is to find out how the implementation of the development strategy and the impact of the implementation of the development strategy for small and micro enterprises in Kweden Village, Tarik Dictrict, Sidoarjo Regency. The type of research used in this research is qualitative research methods and the approach of this research is a acse study approach. The results of this study, it can be concluded that the implementation of the development strategy and the impact of the implementation of the development strategy of micro and small enterprises in Kweden Village is quite good. This is proven by the development of this business being able to recriut employees, especially the community around Kweden Village, which has a very positive impact with the existence of this snack business, which can reduce the level the level of unemployment.
\end{abstract}

Keywords: Business Development, Community Welfare, Maqashid Syariah

Saran sitasi: Maulidah, F. L., \& Oktafia, R. (2020). Strategi Pengembangan Usaha Kecil Dan Mikro Serta Dampak Kesejahteraan Masyarakat Desa Kweden Kecamatan Tarik Kabupaten Sidoarjo (Menurut Pandangan Maqashid Syariah). Jurnal Ilmiah Ekonomi Islam, 6(03), 571-581. doi: http://dx.doi.org/10.29040/jiei.v6i3.1211

DOI: http://dx.doi.org/10.29040/jiei.v6i3.1211

\section{PENDAHULUAN}

Pengembangan merupakan upaya yang dilakukan oleh pemerintah, baik didunia usaha, maupun masyarakat melalui pemberian bimbingan dan bantuan perkuatan untuk menumbuhkan dan meningkatkan kemampuan usaha usaha kecil agar menjadi usaha yang tangguh dan mandiri. Sedangakan menurut Mangkuprawira menyatakan bahwa pengembangan merupakan upaya meningkatkan pengetahuan yang mungkin digunakan segera atau sering untuk kepentingan di masa depan. Pengembangan adalah setiap usaha memperbaiki pelaksanaan pekerjaan yang sekarang maupun yang akan datang, dengan memberikan informasi mempengaruhi sikap-sikap atau menambah kecakapan ( (Mangkupawira, 2014).

Sehubungan dengan pengembangan usaha, hal ini tergantung pada kemampuan pengusaha dan pengelolanya dalam usahanya setiap hari. Menurut
Kamus Besar Bahasa Indonesia, pengembangan adalah proses, cara, perbuatan mengembangkan. Pengembangan merupakan usaha yang terencana dari organisasi untuk meningkatkan pengetahuan, keterampilan, dan kemampuan pegawai. Pengembangan lebih di tekankan pada peningkatan pengetahuan untuk melakukan pekerjaan pada masa yang akan datang, yang dilakukan melalui pendekatan yang terintergrasi dengan kegiatan lain untuk mengubah perilaku kerja (Amenda, 2013).

Setiap manusia tentu mempunyai naluri atau keinginan dalam hidupnya untuk berusaha mencapai apa yang dicita-citakan. Untuk mencapai keinginan itu manusia selalu berusaha dalam mencapai kehidupan yang lebih baik. Dalam usaha inilah manusia dapat mendirikan berbagai macam usaha yang mendapatkan kesuksesan. Dalam memenuhi kebutuhan manusia, maka usaha dapat menimbulkan adanya dunia usaha yang menciptakan barang dan jasa. Menurut Kamus 


\section{Jurnal Ilmiah Ekonomi Islam, 6(03), 2020, 572}

Besar Bahasa Indonesia, usaha adalah kegiatan dengan menggunakan tenaga pikiran atau badan untuk menyatakan suatu maksud. Usaha adalah melakukan kegiatan secara tetap dan terus-menerus dengan tujuan memperoleh keuntungan, baik yang diselenggarakan oleh perorangan maupun badan usaha yang berbentuk badan hukum atau tidak berbentuk badan hukum, yang didirikan dan berkedudukan disuatu daerah dalam suatu Negara (Saputra, 2016)

Data Perkembangan UMKM di Indonesia Tahun 2015-2017 oleh Kementerian Koperasi \& UKM Indonesia menunjukkan bahwa pada tahun 2015 sebesar 59.262.772, tahun 2016 jumlah unit UMKM menjadi 61.651.177, dan pada tahun 2017 mengalami kenaikan sebesar 62.922.617. Dari jumlah unit usaha di Indonesia dikategorikan sebagai UMKM. Data tersebut menunjukkan bahwa peranan UMKM dalam perekonomian Indonesia sangat penting dalam berkontribusi pada peningkatan Produk Domestik Bruto, penyediakan lapangan pekerjaan dan menghasilkan output yang berguna bagi masyarakat guna meningkatkan perekonomian Indonesia (www.depkop.go.id, 2019).

Kegiatan ekonomi adalah suatu usaha untuk meningkatkan daya dan taraf hidup masyarakat, karena dengan semakin meningkatnya pertumbuhan ekonomi maka kebutuhan masyarakat juga akan terpenuhi. Untuk memenuhi kebutuhan masyarakat maka dibutuhkan lapangan pekerjaan yang mampu menyerap setiap angkatan yang ada. Indonesia sebagai negara yang penuh dengan kekayaan alam, belum mampu untuk memaksimalkan potensi yang ada. Masyarakat dituntut untuk lebih mengembangkan kemampuan atau potensi yang ada pada diri sendiri maupun yang berada di wilayah masing-masing sehingga kebutuhan mereka bisa terpenuhi (Rifai, 2012).

Dalam rangka memenuhi kebutuhan hidup agar menjadi sejahtera, masyarakat yang mempunyai kemampuan dan jeli melihat potensi diri serta mampu mengidentifikasi lingkungan, dapat menemukan peluang dan membuka peluang usaha bagi masyarakat. Dengan adanya peluang usaha tersebut, diharapkan dapat membantu pertumbuhan ekonomi masyarakat sekitar menjadi lebih baik sehingga mampu mengurangi tingkat pengangguran yang tinggi. Selain itu, dengan adanya usaha yang menitik beratkan pada peluang yang ada di daerah sekitar, diharapkan mampu menjadi ikon atau ciri khas dari daerah tersebut (Basar, 2015)
Oleh karena itu, Usaha yang dilakukan untuk memenuhi kebutuhan hidup diantaranya dengan melakukan Usaha Mikro Kecil dan Menengah (UMKM). UMKM merupakan bagian dari dunia usaha yang mana kegiatan ekonomi rakyat yang mempunyai kedudukan, peran dan potensi strategis untuk mewujudkan struktur perekonomian nasional yang berlandaskan demokrasi ekonomi. Masyarakat menyadari realitas kehidupan yang ada belum sesuai dengan kondisi ideal. Berdasarkan kesadaran itu masyarakat mempunyai dorongan untuk melakukan sesuatu tindakan guna mewujudkan kondisi yang diidealkan tersebut.

Tindakan tersebut pada dasarnya adalah proses perubahan menuju kondisi yang semakin sejahtera yang disebut sebagai proses pembangunan masyarakat. Dengan demikian tidak berlebihan apabila dikatakan bahwa pembangunan masyarakat merupakan misi yang dijalankan oleh masyarakat untuk mewujudkan visinya. Berkaitan dengan kesejahteraan sebagai visi masyarakat, maka pembangunan masyarakat merupakan upaya untuk mewujudkan kondisi sejahtera tersebut (Adi I. R., 2013).

Keberadaan UMKM hendaknya diharapkan dapat memberi konstribusi yang cukup baik terhadap kesejahteraan masyarakat khususnya dalam upaya penanggulangan masalah-masalah yang sering dihadapi seperti tingginya tingkat kemiskinan, besarnya jumlah pengangguran, ketimpangan distribusi pendapatan dan segala aspek yang tidak baik. Peranan UMKM di Indonesia yang dikaitkan oleh pemerintah hendaknya harus dapat mengurangi tingkat pengangguran yang semakin bertambah dari tiap tahun, menanggulangi kemiskinan dengan membantu masyarakat yang kurang mampu dan pemerataan pendapatan yang dapat memperbaiki kehidupan masyarakat yang memiliki keterbatasan dalam keuangan khususnya (Soetomo, 2014).

Kesejahteraan merupakan cita-cita sosial yang tidak hanya diangankan untuk dimiliki, tetapi juga harus diusahakan. Tanpa usaha dan kerjasama diantara berbagai macam pihak, kesejahteraan merupakan fortamorgana. Bekerja dan berusaha untuk mendapatkan kesejahteraan yang lebih baik serta mendapatkan kebahagiaan di dunia dan akhirat merupakan salah satu perintah yang di anjurkan dalam Islam. Banyak jenis usaha atau pekerjaan yang bisa di lakukan oleh manusia baik secara individu maupun secara kelompok, dengan tidak melanggar segala 
aturan syariat Islam agar mendapatkan keberkahan dalam hidup dunia dan akhirat (Karim, 2014)

Kesejaheraan ekonomi sangat erat hubangannya dengan proses produksi. Konsep kesejahteraan ekonomi dalam Islam terdiri dari bertambahnya pendapatan yang diakibatkan oleh meningkatnya produksi dari barang yang berfaedah melalui pemanfaatan sumber daya yang ada secara maksimum, baik manusia maupun benda, selanjutnya diiringi dengan perbaikan sistem produksi, ditandai dengan terpenuhinya kebutuhan maksimal dengan usaha minimal namun dalam hal konsumsi tetap berpedoman pada nilai-nilai keislaman. Konsumsi yang dilakukan dalam konsep Islam merupakan seseorang yang mengkonsumsi barang atau jasa yang bermanfaat dan berguna bagi dirinya, dalam hal ini adalah mengkonsumsi yang tidak berlebihan atau tidak mengkonsumsi hal-hal yang hanya untuk memuaskan hasrat penasaran dan selanjutnya hanya menghambur-hamburkan uang (konsumtif).

Pada umumnya pembangunan ekonomi yang dilakukan negara berkembang mempunyai tujuan untuk menciptakan pembangunan ekonomi yang hasilnya akan mampu dirasakan oleh masyarakat, misalnya dengan menciptakan lapangan kerja yang bertujuan untuk pemerataan distribusi pendapatan dan mengurangi angka pengangguran. pengembangan kegiatan ekonomi berdasarkan pada kreatifitas, keterampilan, bakat individu yang bernilai ekonomi dan berpengaruh pada kesejahteraan masyarakat Indonesia (Rifai B., 2012).

UD. Jaya Usaha Snack didirikan pada tahun 2009 di Desa kweden Kecamatan Tarik Kabupaten Sidoarjo oleh ibu Niswatin. Yang mana usaha ini didirkan untuk membantu masyarakat sekitar mengurangi pengangguran. dapat dilihat dari jumlah karyawan usaha yang semakin banyak. Hal ini juga tidak terjadi secara langsung akan tetapi membutuhkan proses waktu yang panjang serta diiringi dengan adanya proses pengembangan usaha untuk mencapai suatu targed yang dibutuhkan oleh usaha tersebut. Dengan adanya usaha kecil dan mikro yang berada diwilayah Tarik Khususnya di Desa Kweden ini menjadi pendongkrak untuk ekonomi masyarakat sekitar dan mengurangi pengangguran.

\section{Rumusan Masalah}

a. Bagaimana Strategi Pengembangan Usaha Kecil Dan Mikro Bagi Masyarakat Desa Kweden Kecamatan Tarik Kabupaten Sidoarjo ? b. Bagaimana Dampak Strategi Pengembangan Usaha Kecil Dan Mikro Bagi Kesejahteraan Masyarakat Desa Kweden Kecamatan Tarik Kabupaten Sidoarjo?

\section{Tujuan Penelitian}

1. Untuk mengetahui Bagaimana Strategi Pengembangan Usaha Kecil Dan Mikro Bagi Masyarakat Desa Kweden Kecamatan Tarik Kabupaten Sidoarjo.

2. Untuk mengetahui Bagaimana Dampak Strategi Pengembangan Usaha Kecil Dan Mikro Bagi Kesejahteraan Masyarakat Desa Kweden Kecamatan Tarik Kabupaten Sidoarjo.

\section{METODE PENELITIAN}

\section{Jenis Penelitian}

Peneliti memilih menggunakan metode penelitian jenis kualitatif. Metode penelitian kualitatif merupakan metode penelitian yang lebih memfokuskan pada aspek pemahaman secara mendalam terhadap suatu masalah daripada melihat permasalahan untuk penelitian generalisasi. Penelitian ini mencoba untuk meminta kepada orang-orang untuk mengungkapkan berbagai pikiran mereka tentang suatu topik banyak arahan atau pedoman sehingga dapat mengungkapkan dengan kata-kata yang berasal langsung dari pendapat mereka (Moleong, 2015). Pendekatan penelitian menggunakan studi kasus, Studi kasus merupakan penelitian yang ditujukan untuk menggambarkan situasi atau kejadian yang terjadi.

\section{Lokasi Penelitian}

Dalam melakukan penelitian ini, peneliti melakukan lokasi penelitian di UD. Jaya Usaha Snack yang berada di desa Kweden Kecamatan Tarik Kabupaten Sidoarjo. Karena UD. Jaya Usaha Snack ini yang paling unggul diantara usaha yang lainnya. Hal ini telah terbukti bahwa UD. Jaya Usah Snack sudah banyak menyerap tenaga kerja sebanyak 45 orang karyawan serta memiliki berbagai varian produk yang telah di produksinya. Untuk mendapatkan hasil penelitian secara terfokus, maka peneliti akan menentukan objek penelitian pada suatu tempat tentang strategi pengembangan usaha kecil dan mikro serta dampaknya bagi kesejahteraan masyarakat yang menjadi karyawan di usaha kecil dan mikro tersebut. 


\section{Jurnal Ilmiah Ekonomi Islam, 6(03), 2020, 574}

\section{Teknik Pengumpulan Data}

Penelitian ini menggunakan tiga teknik pengumpulan data yaitu antara lain:

a. Observasi

Teknik pengumpulan data yang digunakan dalam penelitian ini menggunakan jenis observasi partisipasi pasif. Dimana dalam penelitian ini peneliti datang ketempat kegiatan yang diobservasinya akan tetapi tidak ikut serta dalam aktivitas orang yang diamati, hanya sebagai pengamat dalam kegiatan yang diobservasinya. Dalam penelitian ini, observasi dilakukan saat peneliti terjun langsung ke UD. Jaya Usaha Snack di Desa Kweden dan mengamati kegiatan yang dilakukan oleh informan serta observasi ini dilakukan selama 2 bulan (Sugiyono, 2015, hal. 226)

b. Wawancara

Dalam melakukan teknik pengumpulan data yang digunakan oleh peneliti adalah wawancara terstuktur, yaitu dalam usaha memperoleh informasi untuk mencapai tujuan penelitian, maka peneliti melakukan tanya jawab dan bertatap muka antara pewawancara dengan informan atau orang yang diwawancarai, dengan cara telah menyiapkan instrumen penelitian berupa pertanyaan tertulis dan alternatif jawabannya pun telah disiapkan (Sugiyono, 2015, hal. 233). Wawancara dalam penelitian ini di gunakan untuk mendalami suatu kejadian dari subyek penelitian dalam memperoleh data terkait strategi pengembangan usaha kecil dan mikro serta dampaknya bagi kesejahteraan masyarakat.

c. Dokumentasi

Penelitian ini menggunkan pengumpulan data dokumentasi yang dimana dokumentasi tersebut merupakan peristiwa yang sudah berlalu seperti sejarah berdirinya serta perkembangan UD. Jaya Usaha Snack, pertanyaan wawancara, foto saat penelitian. biasa berbentuk tulisan, gambar atau karya seseorang. Jadi semua hasil foto, pertanyaan dan dokumentasi yang didapat saat wawancara di UD. Jaya Usaha Snack lainnya terkait dengan penelitian harus dilampirkan sebagai pendukung hasil penelitian (Sugiyono, 2015, hal. 240)

\section{Teknik Analisis Dan Intreprestasi Data}

Teknik analisis data yang digunakan peneliti pada penelitian ini adalah data selama dilapangan model Miles dan Huberman yang terdapat dalam buku sugiyono (Sugiyono, Metode Penelitian Kuantitatif Kualitatif R\&D, 2019) a. Reduksi Data

Dalam penelitian ini peneliti memilih dan menyederhanakan data mengelompokan data dari catatan tertulis saat observasi dan wawancara terkait strategi pengembangan usaha serta dampak strategi pengembangan usaha kecil dan mikro terhadap kesejahteraan masyarakat yang menjadi karyawan UD. Jaya Usaha Snack. kemudian menjadi kesatuan data yang lengkap. Reduksi data tersebut dilakukan agar dapat memudahkan peneliti pada saat menyajikan data.

b. Penyajian Data

Proses yang dilakukan selanjutnya setelah mereduksi data merupakan proses pemyajian data. Dalam penelitian ini penyajian data akan disajikan dengan uraian teks yang bersifat naratif yang berasal dari kutipan-kutipan wawancara penelitian informan terkait strategi pengembangan usaha serta dampak strategi pengembangan usaha terhadap peningkatan kesejahteraan masyarakat yang menjadi karyawan UD. Jaya Usaha Snack di Desa Kweden.

c. Penarikan Kesimpulan

Langkah terakhir yang dilakukan dalam analisis data adalah penarikan kesimpulan. Dengan langkah ini maka diharapkan dapat menjawab rumusan masalah terkait strategi pengembangan usaha serta dampak strategi pengembangan usaha terhadap peningkatan kesejahteraan masyarakat yang menjadi karyawan UD. Jaya Usaha Snack di Desa Kweden.

\section{Uji Kreadibilitas}

Uji kreadibilitas dalam penelitian yang dilakukan peneliti adalah menggunakan metode triangulasi. Triangulasi dalam pengujian diartikan sebagai pengecekan data dari berbagai sumber dengan berbagai cara, dan berbagai waktu. Terdapat triangulasi sumber, triangulasi teknik dan triangulasi waktu. Triangulasi bertujuan untuk menguji keabsahan data penelitian kualitatif. Dalam penelitian ini peneliti memilih menggunakan triangulasi teknik. Triangulasi sumber, dan triangulasi waktu untuk menguji keabsahan data penelitian (Moleong L. J., 2015)

a. Triangulasi Sumber

Triangulasi sumber untuk menguji kreadibilitas data dapat dilakukan dengan pengecekan data yang telah diperoleh melalui beberapa sumber atau informan lain. Data yang telah diperoleh dianalisis oleh peneliti sehingga menghasilkan suatu kesimpulan, Peneliti disini menggali informasi dari 
sumber secara langsung yakni pemilik usaha dan karyawan usaha Desa Kweden untuk memastikan data wawancara yang diberikan informan benar adanya.

b. Trianglusai Teknik

Triangulasi teknik untuk menguji kreadibiltas data dilakukan dengan cara pengecekan data kepada sumber yang sama dengan teknik yang berbeda. Tujuannya untuk memastikan data bahwa hasil wawancara memang benar dan tidak menghasilkan data yang berbeda saat di cek ulang dengan melakukan cara yang berbeda pula melalui dokumentasi serta pertanyaan wawancara.

c. Triangulasi Waktu

Untuk mendapatkan data yang valid peneliti mengumpulkan data melalui wawancara untuk menguji keabsahan data pada saat hasil dari analisis data sudah didapatkan. Peneliti akan melakukan pengecekan data hasil wawancara dalam waktu dan situasi yang berbeda. Apabila mendapatkan hasil uji yang berbeda maka dapat dilakukan secara berulang sampai mendapatkan kepastian datanya.

\section{HASIL DAN PEMBAHASAN}

\section{Sejarah Singkat Berdirinya UD. Jaya Usaha Snack}

Awal mula berdirinya usaha UD. Jaya Usaha Snack ini pada tahun 2009, UD. Jaya Usaha Snack ini berdirinya karena keadaan pemilik usaha saat itu sedang mendesak. yang mana pemilik usaha ini awalnya bekerja sebagai buruh pabrik biasa dan suaminya juga sebagai buruh pabrik, akhirnya setelah mempunyai keturunan pemilik UD. Jaya Usaha Snack ini tidak diperbolehkan bekerja lagi oleh suaminya. Dengan tidak bekerja lagi akhirnya penghasilan tiap bulannya berkurang, yang awalnya memiliki dua pendapatan yang dihasilkan perbulannya saat ini hanya memiliki satu penghasilan karena tidak diporbelahkan kerja lagi sama suami. Kemudian pemilik usaha memikirkan usaha apa yang cocok untuk dikerjakan dirumah sambil mengurus anak. Akhirnya pemilik usaha memutuskan untuk mendirikan usaha snack ini karena pemilik usaha pribadi juga suka membuat aneka snack.

Pada awal mula berdirinya usaha ini banyak rintangan dan hambatan yang sering terjadi pada usaha ini, akan tetapi dengan kegigihan pemilik usaha tersebut akhirnya bisa melewati beberapa rintangan dan hambatan yang sering terjadi. Awal mula pemilik usaha memasarkan produk ini sangat melelahkan yang mana harus menawarkan ke beberapa grosir dipasarpasar. Seiring dengan berjalannya waktu akhirnya mempunyai pelanggan sendiri yang mana sampai saat ini pelanggan UD. Jaya Usaha Snack sudah sampai beberapa kota. Untuk saat ini para pelanggan yang jauh-jauh sudah tidak lagi harus datang ke tempat untuk melihat barang yang dimintanya ready atau tidak, sekarang bisa tinggal tlvon saja. Misal yang snack yang dibutuhkan oleh pelanggan apa lalu pemilik usaha tinggal mengirim ketempat tujuan pelanggan, jika pelanggan ingin mengambil barang dan langsung datang ketempat pemilik usaha tidak mempermasalahkan hal tersebut.

Pada tahun 2009 hanya memiliki 5 orang karyawan saja, seiring dengan berjalannya waktu akhirnya kini karywan di UD. Jaya Usaha Snack ini menjadi 45 orang karyawan. Yang mana rata-rata karyawan yang bekerja di UD. Jaya Usaha Snack ini adalah masyarakat sekitar. Dengan adanya usaha ini para masyarakat sekitar yang tidak bisa bekerja akhirnya bisa bekerja lagi dan bisa menambah penghasilan keluarganya, yang mana karyawan di UD. Jaya Usaha Snack ini sebagaian besar ibu-ibu yang sudah mempunyai keluraga. Dengan bertambahnya karyawan yang ada di UD. Jaya Usaha Snack ini bisa menambah varian produksi. Yang mana awalnya UD. Jaya Usaha Snack ini hanya memproduksi kacang sembunyi saja, kini UD. Jaya Usaha Snack bisa memiliki 3 varian produksi snack. kemudian produksi snack yang dikelola selama ini oleh UD. Jaya Usaha Snack semain bertambah peminatnya dengan banyaknya varian snack yang di jual.

\section{Perkembangan UD. Jaya usaha Snack}

Pada tahun 2009 UD. Jaya Usaha Snack ini mulai berdiri dan mempunyi lima orang karyawan sebagaian besar karyawaan dari usaha ini adalah masyarakat sekitar sendiri. Dari awal berdirinya usaha ini hanya memproduksi satu produk snack saja yakni kacang sembunyi, karena saat itu lahan juga masih menyewa dan sempit sekitar lahan juga masih banyak tanah kosong. Dengan seiring berjalannya waktu pada waktu itu tahun 2011 usaha snack ini semakin tahun menambah karyawan dan juga produksi semakin banyak serta pesanan juga melonjat tinggi, dengan bertambahnya karywan dan juga orderan semakin banyak akhirnya lahan yang kita tempati juga tidak cukup saat itu terjadi sampai tahun 2013.

Pada tahun 2014 UD. Jaya Usaha Snack ini sudah mempunyai 25 orang karyawan dan produk snack yang di produksi juga menjadi 2 varian yakni keripik pisang dan kacang sembunyi, tahun 2016 lahan yang 
awalnya hanya menyewa kini sudah tidak menyewa lagi. Dengan bertambahnya karyawan dan juga produk yang di produksi semakin banyak kini usaha snack semakin dikenal masyarakat dan para konsumen juga banyak yang dari luar kota. Hal tersebut menjadikan usaha snack ini semakin berkembang dan banyak peminatnya karena rasa dan kwalitas yang berbeda dengan usaha snack yang lainnya hal tersebut terjadi sampai tahun 2017.

Pada tahun 2018 dengan inovasi pemilik usaha kini UD. Jaya Usaha Snack menambah varian produk baru lagi yakni keripik usus, yang menurut pemilik usaha keripik usus kini sudah familiar dikalangan masyarakat. Banyak usaha snack diluar sana yang belum bisa memproduksi keripik usus ini karena cara mengelolahnya sedikit sulit dan memakan waktu yang lama. Hal ini yang menjadikan UD. Jaya Usaha Snack semakin banyak peminantnya, dan dengan adanya produk keripik usus ini permintaan produksinya juga semakin banyak, hingga sampai saat ini per februari tahun 2020 usaha snack ini memiliki karyawan sebanyak 45 orang.

\section{Strategi Pengembangan Usaha Kecil Dan Mikro Bagi Masyarakat Di Desa Kweden Kecamatan Tarik Kabupaten Sidoarjo}

Dalam mengembangkan suatu usaha terdapat strategi yang harus diterapkan. Strategi merupakan langkah-langkah yang harus dijalankan oleh suatu perusahaan untuk mencapai tujuan. Dalam mencapai tujuan, langkah yang harus dihadapi bersifat terjal dan berliku-liku, namun ada pula langkah yang relatif mudah. Disamping itu banyak rintangan atau cobaan yang dihadapi untuk mencapai tujuan, oleh karena itu setiap langkah harus dijalankan secara hati-hati dan terarah (Hendro, 2011).

Keberadaan usaha kecil dan mikro dilingkungan masyarakat memiliki peran yang cukup besar seperti menyerap tenaga kerja di lingkungan masyarakat yang menghasilkan produk yang dibutuhkan dan mengembangkan kreatifitas. Salah satu manfaat keberadaan usaha kecil dan mikro di desa Kweden yaitu menyerap tenaga kerja, serta dapat mengurangi pengangguran dan menambah pendapatan masyarakat sekitar dan secara tidak langsung dapat meningkatkan taraf hidup para pekerjanya.

Pengembangan usaha di UD. Jaya Usaha Snack merupakan salah satu strategi dalam mencapai tujuan untuk meningkatkan kesejahterakan masyarakat yang menjadi karyawan di usaha snack tersebut. Serta untuk mewujudkan masyarakat yang mandiri dalam bekerja, mampu membangun dan memelihara usaha yang telah didirikan dan bisa menjadi kontribusi untuk memenuhi kebutuhan sehari-hari. Terdapat beberapa stategi yang biasa digunakan dalam pengembangan usaha kecil dan mikro menurut (Hendro, 2011) terbagi menjadi :

a. Menjalankan Usaha yang Halal

Kehalalan dalam islam merupakan segala sesuatu usaha yang sangat penting dan harus benar-benar dijaga bagi para pelaku usaha yang baik. Karena mayoritas masyarakat sekitar usaha snack beragama islam maka apabila akan mengkonsumsi makanan yang halal. Baik dalam bentuk makanana, minuman, dan sebagainya. Maka dari itu, pemilik usaha serta karyawan UD. Jaya Usaha Snack mereka tetap menjaga produk yang di produksinya dengan baik sehingga tidak ada barang yang tercampur selain bahan yang mereka pakai.

b. Penentuan Tenaga Kerja

Tenaga kerja merupakan faktor pendukung bagi yang menjalankan usaha, karena apabila tidak ada tenaga kerja tentu usaha yang sedang dimiliki tidak dapat berjalan dengan baik. Oleh karena itu tenaga kerja menjadi hal pokok untuk menjalankan usaha. Dapat dilihat dari karyawan UD. Jaya Usaha Snack usaha snack tersebut mereka sangat bersungguhsungguh dalam menjalankan pekerjaan dan mampu mendukung dalam mengembangkan usaha.

c. Menjaga kualitas jenis produk

Dalam menjalankan suatu usaha tentu saja harus memepersiapkan produk-produk yang akan dipasarkan, untuk itu UD. Jaya Usaha Snack memiliki 3 varian jenis produk yakni keripik pisang, kacang sembunyi dan keripik usus. Oleh karena itu, setiap pemilik usaha harus harus pandai-pandai dalam menciptakan varian makanan apa saja yang banyak diminati oleh masyarakat sekitar. Dalam mengembangkan usahanya UD. Jaya Usaha Snack tetap jaga kualitas rasa yang di produksinya tanpa mengurangi rasa serta ukuran snack yang sudah dibuat oleh pemilik usaha, menjaga variasi jenis produk agar lebih menarik serta memberikan harga yang terjangkau untuk semua kalangan. Maka UD. Jaya Usaha Snack bisa terus mengembangkan usahanya dan bisa bertahan sejak dulu karena sejauh ini usaha snack tidak ada permasalahan dalam menjaga kualitas produknya. 


\section{Jurnal Ilmiah Ekonomi Islam, 6(03), 2020, 577}

d. Pelayanan dan menjaga hubungan baik dengan customer

Dalam menjalankan usaha, pelayanan harus tetap diperhatikan sebagaimana pelayanan dalam menjalankan usaha itu tentu harus baik. Dan dapat menarik perhatian pelanggan, sehingga pelanggan lebih tertarik untuk membeli produknya. Sehingga customer akan kembali untuk membelinya. Dengan seperti itu tentu saja bisa menjalin hubungan yang baik dengan pelanggan dan membuat usaha yang dijalankan oleh pemilik UD. Jaya Usaha Sanck bisa berjalan dengan lancar. Sehingga usahanya dapat berkembang lebih baik lagi. Dengan adanya cara ini UD. Jaya usaha Snack dapat menjalin hubungan baik dengan customer dalam hal tidak mengecewakan mereka dalam pengiriman tepat waktu dan komplain dari customer segera di perbaiki supaya para customer tidak pindah.

e. Modal

Modal merupakan hal yang terpenting dalam memulai usaha yang akan dijalankan. Jadi modal menjadi pendukung untuk mengembangkan usaha. Apabila modal yang dimiliknya sangat minim maka usaha tersebut juga tentu tidak bisa berkembang sebagaimana mestinya. Maka dari itu, UD. Jaya Usaha Snack tetap mengutamakan modal sebagai pengembangan usaha agar kedepannya lebih banyak varian produk yang akan dijual.

Pemilik UD. Jaya Usaha Snack membimbing dan mendampingi semata-mata untuk mengembangan usaha snack agar para karyawan tetap bisa menjaga kualitas rasa yang sudah dibuat oleh pemilik, bimbingan sendiri merupakan proses yang dilakukan oleh pemilik usaha untuk membantu atau membimbing karyawan, baik membantu dari segi finansial, tenaga, fikiran dan lainnya. Salah satu bentuk bimbingan yakni dengan cara mengelilingi karyawan yang sedang kerja jika ada yang salah langsung diperingatkan sehingga karyawan tidak akan mengulangi kesalahan yang sama.

Suatu usaha kecil dan mikro pastinya mempunyai banyak rencana untuk meningkatkan usahanya, sehingga hal serupa juga terjadi pada UD. Jaya Usaha Snack yang mempunyai rencana kedepannya untuk membuka cabang. Permintaan dari karyawankaryawan yang bekerja di UD. Jaya Usaha Snack telah penuh dan tempat untuk memproduksi juga sempit, untuk orang-orang yang ingin mendapatkan penghasilan juga bisa bekerja di usaha tersebut. Hal ini menjadikan pemikiran baru yang harus dihadapi oleh pemilik usaha. Saat ini pemilik UD. Jaya Usaha Snack telah mendapatkan gambaran tempat untuk membuka usaha yang baru. Supaya bisa menampung karyawan yang mengeluh akan tempat yang kurang memadai.

Strategi pengembangan usaha snack tentu harus berlandasan dengan nilai-nilai yang telah ditetapkan oleh Allah dan juga Rasul-Nya. Bentuk usaha yang di jalankan oleh UD. Jaya Usaha Snack telah sesuai dengan perintah Allah SWT dengan menjalankan usaha tidak dengan menipu pelanggan, tidak memaksa dan juga saling terbuka antara pembeli dan juga penjual, sebagaimana dalam mengembangkan usahanya harus berlandaskan iman kepada Allah SWT, menjahui segala larangan-Nya dan menjalankan perintah-Nya. Menjalankan usaha semata-mata untuk mendapatkan keberkahan hidup di dunia dan diakhirat. Sebagaimana Rasulullah SAW merupakan seorang pembisnis yang handal dan sukses, di mana beliau menjalankan usahanya atas dasar kejujuran dan keadilan, tidak pernah melanggar aturan Allah SWT dan transparan dalam menjalankan bisnisnya. Hal ini akan menjadi contoh bagi umat manusia pada saat menjalankan usahanya.

Oleh karena itu, pemilik usaha dan juga para karyawan UD. Jaya Usaha Snack mereka sangat memperhatikan hal tersebut dalam menjalankan usahanya, sehingga usaha yang sedang dijalankan tidak ada permasalahan dalam segi pelayanan terhadap customer dan menjaga kualitas produknya. Sehingga UD. Jaya Usaha Snack mampu menjalankan usahanya dan terus mengembangkan usahanya sampai bisa bertahan sejak dulu hingga saat ini. Hal yang terpenting harus dimiliki oleh pemilik usaha adalah, dengan cara menjalankan segala jenis pekerjaan sesuai dengan aturan-aturan agama islam. dimana kehidupan yang ada di dunia ini merupakan jembatan bagi manusia untuk menuju akhirat yang merupakan tempat kehidupan yang abadi.

Dari penelitian di UD. Jaya Usaha Snack didapatkan bahwa hasil produksi yang dilakukan oleh usaha snack yang ada di Kecamatan Tarik telah memenuhi tujuan dari produksi itu sendiri menurut Islam yakni menyediakan dan menciptakan sesuatu yang bernilai dan berguna bagi masyarakat baik berupa barang maupun jasa. Barang yang dimaksud adalah hasil dari produksinya berupa makanan ringan, sedangkan jasa adalah kegiatan produksi tersebut yang telah memberikan peluang positif bagi masyarakat sekitar dalam hal pekerjaan. 
Keberadaan UD. Jaya Usaha Snack dilingkungan masyarakat desa Kweden memiliki manfaat seperti menyerap tenaga kerja dilingkungan masyarakat sekitar sendiri yang menghasilkan produk yang dibutuhkan dan mengembangkan kreatifitas. Salah satu manfaat keberadaan UD. Jaya Usaha Snack di desa Kweden ini yaitu menyerap tenaga kerja, mengurangi angka pengangguran dan dapat menambah penghasilan masyarakat sekitar, serta secara tidak langsung dapat meningkatkan taraf hidup para karyawan usaha snack. Dan hal ini berarti, para masyarakat sekitar yang menjadi karyawan usaha snack ikut andil dalam mengurangi pengangguran di desa Kweden. Disamping itu keberadaan UD. Jaya Usaha Snack ini juga telah berperan untuk membentuk ibu-ibu menjadi manusia produktif karena telah bisa memanfaatkan waktu luangnya untuk membantu meningkatkan produktifitas produksi yang oleh UD. Jaya Usaha Snack.

\section{Dampak Strategi Pengembangan Usaha Kecil Dan Mikro Bagi Kesejahteraan Masyarakat Menurut Pandangan Maqashid Syariah}

Dalam menjalankan suatu usaha pasti mempunyai strategi, yang mana strategi tersebut mempunyai dampak. Dampak merupakan suatu perubahan yang terjadi sebagai akibat dari suatu aktivitas atau tindakan yang dilaksanakan sebelumnya yang merupakan konsekuensi dari dilaksanakannya suatu kebijakan sehingga akan membawa perubahan positif (Soemarto, 2013). Implementasi strategi pengembangan UD. Jaya Usaha Snack akan berdampak positif terhadap masyarakat dan karyawan sekitar desa Kweden. Bisa bersifat langsung maupun tidak langsung. Bersifat langsung maupun tidak langsung maksudnya dapat dilihat dari pekerja/karyawan di usaha snack itu sendiri yang mana mereka dengan adanya usaha snack ini mereka dapat menambah penghasilan tetap setiap bulannya.

Menjalankan suatu usaha kegiatan usaha seperti berdagang merupakan kegiatan yang diRidhai oleh Allah SWT, dimana usaha tersebut harus terus dikembangkan agar lebih baik ke depannya. Dalam mengembangkan usaha seperti memasarkan dan mengelola produk yang akan disalurkan ke masyarakat tentu harus diperhatikan agar usaha yang dijalankan tidak menimbulkan kemudharatan. Islam sangat mendukung manusia yang mau berusaha dengan cara bekerja sehingga mampu memperbaiki taraf hidupnya, bekerja di pandang sebagai ibadah oleh Allah SWT.

Kehidupan manusia di dunia pada hakikatnya adalah untuk melaksanakan usaha agar sukses dunia maupun akhirat menurut Islam. Allah SWT telah memberikan nikmat berupa panca indera, fisik, akal, dan lain sebagianya untuk dapat dioptimalkan oleh manusia sebaik- baiknya. Dengan melakukan usaha dengan sebaik-baiknya maka Allah pun akan memberikan rezeki dan karunia tersebut. Hal ini tidak akan datang kepada manusia yang berdiam diri saja tanpa melakukan apapun.

Di dalam Islam kesejahteraan masyarakat tidak hanya di ukur melalui materialisme, atau biasa disebut dengan masyarakat yang memiliki harta yang berlimpah, di dalam ajaran Islam kesejahteraan masyarakat juga termasuk kedalam maqasid syari'ah yaitu memiliki tujuan yang sesuai dengan tuntunan syariah seperti terlindungnya kesucian agama, terlindungnya akal, kehormatan dan terpenuhi hak ekonominya.

Adapun dampak pengembangan strategi usaha kecil dan mikro dalam upaya meningkatkan kesejahteraan masyarakat yang menjadi karyawan pada UD. Jaya Usaha Snack. Dengan cara mengimplementasikan program peningkatan kualitas hidup masyarakat, yang sejalan dengan implementasi kesejahteraan berdasarkan prespektif maqashid syariah, dimana terdapat lima poin indikator peningkatan kualitas hidup masyarakat dalam maqashid syariah. Pada masing-masing poin indikator tersebut memiliki tingkatan yang lebih dominan dirasakan karyawan UD. Jaya Usaha Snack sebagai berikut:

a. Peningkatan kesejahteraan pada indikator agama (hifz ad-din)

Adanya UD. Jaya Usaha Snack yang berada di desa kweden para masyarakat sekitar bisa bekerja di usaha snack tersebut. Maka dari itu, UD. Jaya Usaha Sanck didirikan dengan tujuan selain mendapatkan keuntungan juga usaha snack dapat membantu para masyarakat sekitar untuk bekerja dan mendapatkan penghasilan yang halal setiap bulannya. Dari menjalankan usaha yang halal tersebut maka karyawan bisa menyisihkan sebagaian dari pendapatannya untuk beramal jariyah. 


\section{Jurnal Ilmiah Ekonomi Islam, 6(03), 2020, 579}

b. Peningkatan kesejahteraan pada indikator jiwa (hifz an-nafs)

UD. Jaya Usaha Snack dalam implementasi strategi pengembangan usaha salah satunya terdapat penentuan tenaga kerja, dengan adanya penentuan tenaga kerja yang ada di UD. Jaya Usaha Snack akan berdampak pada pemenuhan kebutuhan pokok karyawan. Oleh karena itu, para karyawan yang bekerja di usaha tersebut mereka dapat memenuhi kebutuhan pokok keluarganya setiap hari.

Para karyawan yang bekerja di UD. Jaya Usaha Snack mereka bekerja dengan sungguh-sumgguh dan mampu mendukung usaha tersebut bisa berkembang secara pesat. terlihat perbedaan sebelum dan sesudah bekerja, mereka mampu memenuhi kebutuhan baik berupa peningkatan dalam hal makanan setiap harinya serta kebutuhan yang mendesak seperti kesehatan dan juga pendidikan anak-anak mereka.

c. Peningkatan kesejahteraan pada indikator akal (hifz al-aql)

Setiap manusia pasti memiliki akal, maka untuk mengembangkan usaha strategi yang dilakukan UD. Jaya Usaha Snack yaitu menjaga kualitas produk. Oleh karena itu, para karyawan usaha tetap menjaga kualitas produk dengan cara tanpa mengurangi rasa maupun ukuran snack. Setiap pelaku usaha harus pandai-pandai menjaga kualitas produk sehingga usaha yang sedang dijalankan bisa berjalan dengan lancar. Maka dari itu, UD. Jaya Usaha Snack bisa terus mengembangkan usahanya sejak dulu hingga saat ini.

Salah satu cara untuk tetap bisa mengembangkan usahanya UD. Jaya Usaha Snack memiliki rasa yang khas sehingga usaha snack tidak ada permasalahan dalam menjaga kualitas produknya. UD. Jaya Usaha Snack juga memiliki variasi produk yang menarik serta memberikan harga yang terjangkau bagi semua kalangan.

d. Peningkatan kesejahteraan pada indikator keturunan (hifz an-nashl)

Dalam indikator ini karyawan yang bekerja di UD. Jaya Usaha Snack dapat dijadikan sumber pengetahuan yang mana pengetahuan tersebut dapat disampaikan terhadap anak-anaknya. Pegetahuan tersebut seperti mengajari anak-anaknya dengan menjelaskan bagaimana pelayanan yang baik terhadap customer.

semakin meningkatnya pemahaman pelayanan terhadap customer dalam mengembangkan usaha snack maka perkembangan usaha tersebut semakin baik, sehingga karyawan bisa bekerja di UD. Jaya
Usaha Snack lebih lama dan karyawan juga bisa memenuhi kebutuhan pokok dan kebutuhan pendidikan untuk anaknya.

e. Peningkatan kesejahteraan pada indikator harta (hifz al-maal)

Salah satu peningkatan pendapatan pemilik usaha akan berdampak pada kesejahteraan masyarakat yang menjadi karyawan UD. Jaya Usaha Snack. Yang mana dalam implementasi strategi untuk pengembangan usaha yang dilakukan usaha snack yaitu modal. Oleh karena itu, modal menjadi penopang utama untuk mengembangkan usaha yang sudah dirintis selama ini.

Dengan adanya modal yang menjadikan karyawan dapat peningkatan pendapatan maka karyawan dapat memenuhi kebutuhan hidupnya dengan cara mereka bekerja di usaha snack dan menghasilkan pendapatan setiap bulannya. Dengan bekerja disini mereka juga bisa menyisikan pendapatannya untuk ditabung dan di pergunakan pada masa mendatang.

Keberadaan UD. Jaya Usaha Snack di desa Kweden bisa membantu meningkatkan kesejahteraan masyarakat yang menjadi karyawan di usaha snack tersebut, karena mayoritas karyawan di UD. Jaya Usaha Snack masyarakat sekitar desa Kwden sendiri. Dengan adanya UD. Jaya Usaha Snack di desa kweden mampu membantu meningkatkan kesejahteraan masyarakat yang menjadi karyawan terutama dalam hal peningkatan pendapatan baik itu setiap harinya ataupun setiap bulannya. Masyarakat di desa Kweden yang kebanyakan menjadi ibu rumah tangga dapat terbantu dengan adanya UD. Jaya Usaha Snack sebagai sumber lain untuk menambah pendapatan. Sebelum adanya UD. Jaya Usaha Snack mereka hanya mengandalkan pengahasilan suaminya saja, hal ini menuntut mereka untuk mencari solusi lain yakni dengan ikut terlibat dalam kegiatan UD. Jaya Usaha Snack sebagai pekerja.

Jika dilihat dari beberapa indikator kesejahteraan masyarakat yang telah dijelaskan tersebut menunjukan bahwa keberadaan UD. Jaya Usaha Snack yang berada di desa Kweden memiliki dampak yang cukup baik untuk masyarakat sekitar yang menjadi karyawan usaha sanck tersebut. Yang mana para masyarakat yang saat ini memperoleh pekerjaan dan penghasilan tambahan meskipun masih dikatakan rendah pada umumnya, akan tetapi mereka menganggap bahwa hasil itu dikatakan cukup untuk memenuhi kebutuhan masyarakat baik berupa peningkatan dalam hal setiap harinya serta kebutuhan 
yang mendesak seperti kesehatan dan juga pendidikan anak-anak mereka, selain itu juga karyawan bisa menyisihkan uangnya untuk ditabung dimasa mendatang.

Para karyawan UD. Jaya Usaha Snack sangat bersungguh-sungguh dalam menjalankan dan mengembangkan usaha snack. Agar para karyawan mampu terus memperbaiki tingkat perekonomiannya, bagi karyawan tingkat kesejahteraan tidak hanya di pandang dalam bentuk materi semata, melainkan ketentraman jiwa, merasa nyaman dengan lingkungan sekitar juga merupakan bentuk kesejahteraan. Dalam mensejahterakan hidup, islam menekankan dalam hal pemberantasan kemiskinan, pengangguran, kebodohan, serta malas dan sebagainya.

Oleh karena itu, Kehidupan yang mulia dan kesejahteraan di dunia dan akhirat, dapat terwujud apabila terpenuhi kebutuhan-kebutuhan hidup manusia secara seimbang yang memberikan dampak maslahah yaitu segala bentuk keadaan baik material maupun non material yang mampu meningkatkan kedudukan manusia sebagai mahluk yang paling mulia. Sehingga pemilik usaha UD. Jaya Usaha Snack tidak membeda-bedakan antara karyawan yang satu dengan karyawan yang lain, karena anggapan pemilik usaha semua karyawan dianggap sama dan mereka mempunyai kelebihan masing-masing.

Kegiatan UD. Jaya Usaha Snack di desa Kweden kini sudah mempunyai izin usaha dan proses bahan baku yang digunakan terdiri dari bahan-bahan yang halal. Walaupun demikian usaha ini telah memberikan kontribusi yang besar bagi peningkatan ekonomi masyarakat. Artinya tujuan produksi dalam Islam telah tercapai dengan adanya usaha snack ini. Akan tetapi, usaha snack ini tidak hanya memberikan keuntungan semata bagipemilik usaha, tetapi juga keuntungan bagi masyarakat sekitar, dikarenakan usaha ini telah menyerap tenaga kerja yang ada di Kecamatan Tarik dengan begitu tingkat penganguran di sekitar masyarakat desa Kweden akan menjadi berkurang.

\section{KESIMPULAN}

Dalam mengembangkan usaha kecil dan mikro yang berada di kawasan Desa Kweden kini pemilik usaha snacak memiliki strategi untuk mengembangkan usaha yang dijalankan, seperti halnya dalam strategi pengembangan usaha UD. Jaya Usaha Snack antara lain : menjalankan usaha yang halal, peningkatan tenaga kerja, Menjaga kualitas jenis produk, Pelayanan dan menjaga hubungan baik dengan customer, Modal. Hal ini bertujuan untuk mengembangkan usaha snack, yang digunakan untuk tetap menjaga kualitas rasa yang sudah di buat oleh pemilik tanpa mengurangi rasa sedikitpun, dengan begitu para customer tidak akan kecewa untuk membeli snack di UD. Jaya Usaha Snack, dengan begitu usaha snack tetap bisa berkembang dengan pesat. Dampak strategi pengembangan UD. Jaya Usaha Sanck kini sudah termasuk ke dalam Maqashid Syariah. Indikator Maqashid Syariah terdiri dari: Peningkatan kesejahteraan masyarakat pada indikator agama (hifz ad-din), Peningkatan kesejahteraan pada indikator jiwa (hifz an-nafs), Peningkatan kesejahteraan pada indikator akal (hifz al-aql), Peningkatan kesejahteraan pada indikator keturunan (hifz an-nashl), Peningkatan kesejahteraan pada indikator harta (hifz al-maal). Kemunculan usaha snack di desa kweden benar-benar berdampak positif terhadap peningkatan terhadap kesejahteraan masyarakatnya akibat tingkat penganggurannya berkurang sebab bertambahnya lapangan pekerjaan baru.

\section{DAFTAR PUSTAKA}

Adi, I. R. (2013). Kesejahteraan Sosial. Jakarta: Rajawali Pers.

Adi, M. k. (2015). Analisis Usaha Kecil dan Menengah. Yogyakarta: Andi Offset.

Amenda. (2013). Strategi Pengembangan Usaha Kecil dan Menengah. Jakarta: Fakultas Ekonomi Universitas Indonesia .

Basar, A. M. (2015). Peranan Usaha Kecil dan Menengah Dalam Meningkatkan Kesejahteraan Masyarakat. Cirebon: IAIN Syekh Nurjati.

Hendri. (2014). Pengantar Ekonomika Mikro Kecil Islami. Yogyakarta: Ekonesia.

Hendro, I. (2011). Dasar-Dasar Kewirausahaan. Jakarta: Erlangga.

Hurlock, E. B. (2017). Psikologi Perkembangan Suatu Pendekatan Sepanjang Rentang Kehidupan. Jakarta.

Hutchison, V. G. (2014). Kecenderungan Baru Dalam Pendidikan Ilmu Kesejahteraan Keluarga. Jakarta: Balai Pustaka.

Karim, A. W. (2014). Ekonomi Mikro Islam. Jakarta : Raja Wali Perss.

Manan, A. (2016). Teori dan Praktek Ekonomi Islam. Yogyakarta: Dana Bakti Prima. 
Jurnal Ilmiah Ekonomi Islam, 6(03), 2020, 581

Mangkupawira. (2014). Manajemen Sumber Daya Manusia Strategik. Jakarta: Ghalia.

Moleong, L. j. (2015). Metodologi Penelitian Kualitatif . Bandung: Remaja Rosdakarya.

Mutakin, A. (2017). Teori Maqashid Al-Syariah dan Hubungan dengan Metode Istinbath Hukum. Hukum, 3.

Rifai, B. (2012). Efektivitas Pemberdayaan Usaha Mikro Kecil dan Menengah. Sosio Humaniora, 4.

Rinawati, I. (2013). Pembangunan Ekonomi Dalam Tujuan Maqashid Syariah. Penelitian Dan Kajian Keagamaan, 40.

Riyadi, I. Y. (2013). Prinsip Dasar Ekonomi Islam. Prenadamedia Group, 44.
Saputra, E. P. (2016). Identifikasi Faktor yang Mempengaruhi Sukses. Manajemen dan Bisnis, 1.

Soemarto, O. (2013). Analisis Dampak Lingkungan . Yogyakarta: Gadjah Mada University.

Soetomo. (2014). Kesejahteraan dan Upaya Mewujudkan dalam Prespektif Masyarakat Local. Jakarta: Pustaka Pelajar.

Sugiyono. (2015). Metode Penelitian Kuantitatif Kualitatif $R \& D$. Bandung: Alfabeta.

Sugiyono. (2019). Metode Penelitian Kuantitatif Kualitatif $R \& D$. Bandung: Alfabeta.

Zakariyya, M. M. (2015). Keutamaan Mengutamakan harta. Yogyakarta: Ash-shaff. 